\title{
Characterization of Cassava (Manihot esculenta Crantz) Cultivars in Sri Lanka using Morphological, Molecular and Organoleptic Parameters
}

\author{
U.H.K. Dissanayake ${ }^{1}$, R.W.K.M. Senevirathna ${ }^{1}$, L.T. Ranaweera ${ }^{1}$, \\ W.W.M.U.K. Wijesundara ${ }^{1}$, H.S.M. Jayarathne ${ }^{1}$, C.K. Weebadde ${ }^{2}$ and \\ S.D.S.S. Sooriyapathirana ${ }^{1 *}$
}

Postgraduate Institute of Science

University of Peradeniya

Sri Lanka

\begin{abstract}
Cassava (Manihot esculenta Crantz), an important dietary staple in many countries, supplies food for one billion people in the world. Due to dietary importance, currently cassava cultivation is promoted in Sri Lanka. Even though there are different cassava cultivars grown, no studies have been conducted on cultivar discrimination and preference on their tubers for consumption. Therefore, the present study was conducted to study the morphological and genetic diversity, and assess the consumer preference of cassava cultivars grown in Sri Lanka. Morphological traits of leaves, stems and tubers, chlorophyll content, ascorbic acid content of leaves, dry matter content of leaves and tubers were recorded. The genetic diversity was assessed by sequencing and analyzing the ITS, a DNA barcoding locus. The leaf morphology of wild-accession and Landrace cultivars were considerably different from the rest. The stem morphology was highly different, mainly in the internodal length. A significantly high number of tubers were observed in the cultivar Suranimala. The significant associations were observed from color, aroma, texture, bitterness, hardness and overall taste vs. cassava cultivars. The nine cultivars were separated through ITS polymorphism. In phylogenetic analysis, wild-accession was the most genetically distant type having nine unique SNPs and one INDEL. Other cultivars were mainly divided into two clusters. Thus, it is possible to employ ITS barcoding marker to discriminate the cultivars of M. esculenta.
\end{abstract}

Keywords: Cassava, manioc, SNP profiling, INDEL profiling, UPGMA

\section{INTRODUCTION}

Cassava (Manihot esculenta Crantz) which supplies food for one billion people in the world (Reynolds, 2017; Rodriguez and Sanders, 2015), was originated in South America and mainly cultivated in the tropical and sub-tropical regions of the world (Hershey, 2017). Cassava plays a major role in solving food problems as it grows well and produces stable yields under extreme conditions such as drought, heat stress, diverse environmental and soil conditions (ElSharkawy, 2003). It is a versatile crop which can be processed into a broad range of products including, flour, beer, cassava chips and animal feed (Cock, 1982). Cassava is also gaining

1 Department of Molecular Biology and Biotechnology, Faculty of Science, University of Peradeniya, Sri Lanka

2 Department of Plant, Soil and Microbial Sciences, College of Agriculture and Natural Resources, Michigan State University, East Lansing, MI, USA

* Corresponding author: sunethuop@gmail.com 
more importance by becoming an important biofuel crop (Jansson et al., 2009; Ziska et al., 2009; Adelekan, 2010).

Cassava is propagated mainly by vegetative means (Elias et al., 2001). Therefore, traditionally, morphological descriptors have been the basis for germplasm identification and differentiation (Carvalho and Schaal, 2001). Other than that, isozymes (Lefevre, 1989), biochemical and genetic markers were also used as alternative methods for characterization. Highly heritable traits such as root cortex and less heritable traits such as yield and plant height have been used as vegetative parameters for characterization (Chavarriaga-Aguirre et al., 1999). Carvalho and Schaal, (2001) have identified plant height, root weight and stored root starch content as the most variable morphological parameters among cassava cultivars in a diversity analysis. Due to the identification of potential duplications with isozymes and morphological traits (JimenezNieto, 1994; Ocampo et al., 1993), rapid and less labor-intensive PCR-based DNA marker genotyping systems are required in characterization. Studies of cassava diversity analysis at the molecular level have been successfully carried out using RFLP (Beeching et al., 1993), RAPD (Marmey et al., 1993), SSR (Fregene et al., 2003, Moyib et al., 2007) and multi-locus DNA fingerprinting.

Even though these molecular markers play a major role in cultivar identification and diversity analysis, detection of similar polymorphism in most of the loci within closely related cultivars is a limitation (Kawuki et al., 2009). In contrast, single nucleotide polymorphisms (SNPs), and insertions and deletions (INDELS) give the most frequently occurring natural variation (Kruglyak, 1997) which may provide sufficient disparity to discriminate closely related cultivars. As cassava is an outcrossing (Da Silva et al., 2003) and inbreeding sensitive crop like maize and orchids (Conopsea and Bifolia, 2017; Meghji et al., 1984; Rojas et al., 2009), it is expected to have high DNA polymorphism due to the heterogeneity frequently found in most of the loci. Kawuki et al. (2009) have characterized SNPs in cassava genes and found 26 SNPs in nine loci with an average of one SNP at every 121 nucleotides. They also found one SNP at every $181 \mathrm{bp}$ in coding regions, and one SNP in every $53 \mathrm{bp}$ of non-coding regions. A frequency of one SNP in 66 bp in 33 EST-derived products and one SNP in 49 bp in nine BACend sequence products are also reported in cassava genome (Lopez et al., 2005; Kawuki et al., 2009). Therefore, closely related cassava cultivars can be discriminated using SNP markers due to their frequent distribution throughout the genome.

In Sri Lanka, cassava is mainly grown for direct human consumption rather than for commercial applications although a sound local market exists. Recently, exporting of cassava tubers became an attractive industry in Sri Lanka due to the high demand especially from middle-east countries. So far, no studies have been carried out for cultivar discrimination even though there are several studies published related to disease identification in cassava cultivars (Jose et al., 2008; Kumarasinghe et al., 2009). Therefore, the present study was conducted to characterize the morphological, biochemical and molecular traits and, consumer preference of the cassava cultivars grown in Sri Lanka.

\section{METHODOLOGY}

\section{Plant material}

The stem cuttings of nine cassava cultivars namely; Wild-accession, MU51, Kirikavadi, CARI555, Shani, Suranimala, Swarna, Hordi MU1 and Landrace (a cultivar name) were collected from Horticultural Crop Research and Development Institute, Gannoruwa, 
Peradeniya $\left(7.2757^{\circ} \mathrm{N}, 80.5988^{\circ} \mathrm{E}\right)$ and fields at Doluwa $\left(7.1862^{\circ} \mathrm{N}, 80.6063^{\circ} \mathrm{E}\right)$, Sri Lanka. Two replicates of the Wild-accession and three replicates from each of the other cultivars were grown in a field at Katugastota, Sri Lanka. The uniform stem cuttings were selected for planting to have accurate comparison of the morphological descriptors.

\section{Morphological parameters}

\section{Leaf morphology}

Leaf blade length, leaf blade width, number of leaflets and leaf area were measured in ten leaves from each replicate at the age of seven months. Internodal lengths of four stems from each replicate were measured in which each stem had a length of ten nodes. The mean diameter of each stem was taken by measuring the diameter at three different positions and calculating the mean value. At the harvesting stage, tuber weight, number of tubers, maximum, minimum lengths and maximum, minimum diameters of tubers were measured.

\section{Chlorophyll content of leaves}

Estimation of chlorophyll content was done using two grams of fresh leaf material from each of the three replicates per cultivar. The leaf samples were ground with $2 \mathrm{ml}$ of $80 \%$ acetone using mortar and pestle. Acetone extract of chlorophyll was collected into test tubes by filtering through Whatman filter papers (125 mm, Cat No: 1005 125). The homogenate was washed three times with $1 \mathrm{ml}$ of acetone, and the final volume was made up to $5 \mathrm{ml}$ with $80 \%$ acetone. Then the concentration of total chlorophyll was quantified by reading the optical density at $663 \mathrm{~nm}$ and $645 \mathrm{~nm}$. Finally, the chlorophyll content was calculated using the following formula (Maclachlan and Zalik, 1963).

where,

Total chlorophyll content $(\mathrm{mg} / \mathrm{g})=20.2\left(\mathrm{~A}_{645}\right)+8.02\left(\mathrm{~A}_{663}\right) \times \mathrm{V}_{1000} \times \mathrm{W}$

A $=$ the absorbance at specific wavelengths

$\mathrm{V}=$ the final volume of chlorophyll extract

$\mathrm{W}=$ the fresh weight of tissue extracted

\section{Ascorbic acid content of leaves}

A total of $30 \mathrm{~g}$ of leaves were ground from three replicates of each cultivar using $150 \mathrm{ml}$ of water. Then the ground solution was sonicated and filtered using Whatman filter papers $(2.5 \mu \mathrm{m})$ to use for the titrations. A $10 \mathrm{ml}$ aliquots of each sample was taken into separate beakers and $1 \mathrm{ml}$ of starch indicator solution was added. The samples were titrated with $0.012 \mathrm{~mol} / \mathrm{l}$ iodine solution, and the endpoint of the titration was identified when dark blueblack color appeared due to the formation of the starch-iodine complex. Three titrations were carried out per each replicate and the mean volumes of iodine solution used in concordant titers were used in the calculations and the ascorbic acid concentration was expressed in $\mathrm{mg} / \mathrm{g}$.

\section{Dry matter content of leaves and tubers}

Five leaves from different maturity classes (top to bottom) from each replicate were sampled to get the fresh weight of each leaf sample. Then they were oven dried at $65{ }^{\circ} \mathrm{C}$ for several days until the weight becomes constant. The dry matter content of each replicate was calculated by dividing the dry weight of the leaves (mg) by the fresh weight of the leaves (g). 
Ten tubers of approximately equal size from each replicate were taken, and the fresh weight was recorded. Then the tubers were oven dried and the dry matter content of tubers was calculated using the same calculation procedure described for the leaves.

\section{Assessment of consumer preference of boiled cassava tubers}

Three sensory panels were carried out separately after harvesting the tubers for each replicate. Boiled tuber pieces were provided to 20 panelists to rank them for the desired color, the preferred level of aroma, texture, bitterness, hardness and overall taste. A three-tier scoring system was used for each of the parameters, in which the panelists were requested to assign 3 for the highest preference, 2 for the medium preference and 1 for the least preference.

\section{Data analysis}

All the data of leaf morphology, chlorophyll content, ascorbic acid content and dry matter content were subjected to normality testing followed by GLM procedure and LSmeans-pdiff mean separation using statistical package, SAS 9.4 (SAS Institute, NC, Cary, USA). Principal component analysis (PCA) was conducted using morphological data of leaves and stems in Minitab 17 (Minitab Inc. USA). PC1 and PC2 were obtained to draw scatterplots. Similar procedure was followed to obtained PCA for the tuber parameters (mean number of tubers, mean tuber weight, mean average length and mean average diameter) using Minitab 17 (Minitab Inc. USA). Another scatter plot was constructed employing the mean chlorophyll content and mean dry matter content of leaves.

The taste panel data were subjected to association analysis using the chi-squared test and Cramer's V coefficient (CVC) available in Minitab 17. A dendrogram was constructed by using the taste panel data for color, texture, aroma and overall taste of highest preference and least preference data for hardness and bitterness using the algorithms of Complete Linkage and Euclidean Distance method in Minitab 17.

\section{The DNA extraction and PCR}

Genomic DNA was extracted from leaves using the CTAB method (Doyle, 1991) and DNA was quantified by measuring the absorbance at $260 \mathrm{~nm}$ and $280 \mathrm{~nm}$. The quality of the DNA was visualized using $1 \%$ agarose gel electrophoresis.

The ITS1 (5' TCC GTA GGT GAA CCT GCG G 3') and ITS4 (5' TCC TCC GCT TAT TGA TAT GC 3') (Glass and Donaldson, 1995) primers were used to amplify the ITS region using a Thermal Cycler (TP600: Takara, Otsu Shiga, Japan). The PCR conditions were as follows. For ITS primer pair, initial denaturation was done at $95^{\circ} \mathrm{C}$ for one min, followed by 40 cycles of denaturation at $94^{\circ} \mathrm{C}$ for 30 secs, then annealing at $50.7^{\circ} \mathrm{C}$ for 40 secs. The first extension was done at $72^{\circ} \mathrm{C}$ for $40 \mathrm{secs}$, and a final extension at $72^{\circ} \mathrm{C}$ was carried out for five mins (White et al., 1990). The PCR products were purified using the QIAquick PCR purification kit (Catalog No: 28104, Qiagen, Hilten, Germany). The purified PCR products were sequenced using the Genetic Analyzer 3500 (Catalog No: 622-0010, Applied Bio System®). 


\section{Cultivar discrimination based on ITS sequences}

Initially, the quality of the sequences was checked by curating . $a b l$ sequencer trace file. Then the ambiguous regions were cut from the sequences, and consensus sequences were made using MEGA V7 (Kumar et al., 2016). All the consensus sequences were then aligned using MEGA by the ClustalW algorithm. The alignment was rechecked again for the detection of unwanted INDELs that could be added during the automated aligning. The unweighted pair group method with arithmetic means (UPGMA) tree was built in PAUP V4 (Swofford, 2001) using uncorrected pairwise distances among the sequences. The resulting tree was modified using FigTree 1.6b (Rambaut, 2014). Determination of SNPs and INDELs was carried out by searching the alignment in alignment-explore in MEGA.

\section{RESULTS AND DISCUSSION}

\section{Morphological diversity of leaves}

Except the Landrace $(\mathrm{P}<0.05)$, the length of leaves of other eight cultivars was not significantly different (Plate 1). The mean length of leaves in Landrace was $13.48 \mathrm{~cm}$, significantly different from those of other cultivars (Table 1, P<0.05). Except for Wildaccession and Landrace $(\mathrm{P}<0.05)$, the width of leaves of other seven cultivars was not significantly different. The highest mean width was recorded in Wild-accession $(5.97 \mathrm{~cm})$ revealing significant difference from other eight cultivars. The lowest mean leaf width was observed in Landrace $(3.72 \mathrm{~cm})$ (Table $1, \mathrm{P}<0.05)$. The mean number of leaflets among cassava cultivars was significantly different (Table $1, \mathrm{P}<0.05)$. The lowest mean number of leaflets was recorded in the Wild-accession (4.25) exhibiting significant difference from other eight cultivars (Table 1, P<0.05). The mean number of leaflets in MU51 and Shani was not significantly different $(7.83)$ (Table $1, \mathrm{P}<0.05)$. Except the Landrace, the mean leaf area among other cultivars was not significantly different $(\mathrm{P}<0.05)$. The significantly lowest mean leaf area was observed in Landrace $\left(132.57 \mathrm{~cm}^{2}\right)$ (Table $\left.1, \mathrm{P}<0.05\right)$.

\section{Morphological diversity of stems}

The mean diameters of the stems were significantly different among the cultivars $(\mathrm{P}<0.0001)$. The highest mean diameter was recorded in Wild-accession $(9.567 \mathrm{~cm})$ followed by Swarna $(8.967 \mathrm{~cm})$. The mean diameters of remaining cultivars were not significantly different from each other (Table 2, $\mathrm{P}<0.05$ ).

The mean inter-nodal length of stems was significantly different among the cultivars $(\mathrm{P}<0.0001)$. The highest mean inter-nodal length was recorded in Wild-accession $(4.299 \mathrm{~cm})$ followed by Kirikawadi $(3.909 \mathrm{~cm})($ Table $2, \mathrm{P}<0.05)$. The significantly lowest mean internodal length was observed in the cultivar Landrace $(2.138 \mathrm{~cm})$ (Table 2, $\mathrm{P}<0.05$ ). Plate 2 displays the morphological variation of stems among the cultivars. 
Table 1. Variation of leaf morphology in cassava cultivars

\begin{tabular}{lcccc}
\hline Cultivar & $\begin{array}{c}\text { Mean leaf } \\
\text { length }(\mathbf{c m})\end{array}$ & $\begin{array}{c}\text { Mean leaf } \\
\text { width }(\mathbf{c m})\end{array}$ & $\begin{array}{c}\text { Mean number } \\
\text { of leaflets }\end{array}$ & $\begin{array}{c}\text { Mean leaf area } \\
\left(\mathbf{c m}^{2}\right)\end{array}$ \\
\hline Wild-accession & $16.36^{\mathrm{a}}$ & $5.97^{\mathrm{a}}$ & $4.25^{\mathrm{d}}$ & $198.00^{\mathrm{a}}$ \\
Kirikawadi & $17.81^{\mathrm{a}}$ & $4.93^{\mathrm{b}}$ & $7.07^{\mathrm{c}}$ & $227.97^{\mathrm{a}}$ \\
MU51 & $16.86^{\mathrm{a}}$ & $4.69^{\mathrm{b}}$ & $7.83^{\mathrm{b}}$ & $247.87^{\mathrm{a}}$ \\
CARI555 & $15.07^{\mathrm{a}}$ & $4.30^{\mathrm{b}}$ & $8.17^{\mathrm{a}}$ & $216.23^{\mathrm{a}}$ \\
Shani & $16.75^{\mathrm{a}}$ & $4.36^{\mathrm{b}}$ & $7.83^{\mathrm{b}}$ & $237.20^{\mathrm{a}}$ \\
Suranimala & $15.71^{\mathrm{a}}$ & $4.28^{\mathrm{b}}$ & $7.10^{\mathrm{c}}$ & $178.57^{\mathrm{a}}$ \\
Swarna & $17.01^{\mathrm{a}}$ & $4.96^{\mathrm{b}}$ & $8.37^{\mathrm{a}}$ & $263.67^{\mathrm{a}}$ \\
HordiMU1 & $14.85^{\mathrm{a}}$ & $4.43^{\mathrm{b}}$ & $6.93^{\mathrm{c}}$ & $194.03^{\mathrm{a}}$ \\
Landrace & $13.48^{\mathrm{b}}$ & $3.72^{\mathrm{c}}$ & $6.70^{\mathrm{c}}$ & $132.57^{\mathrm{b}}$ \\
\hline
\end{tabular}

Means denoted by the same letters within the column are not significantly different at $\mathrm{P}<0.05$.

Table 2. Variation of stem morphology

\begin{tabular}{lcc}
\hline Cultivar & $\begin{array}{c}\text { Mean Diameter } \\
(\mathbf{c m})\end{array}$ & Mean Inter-nodal length (cm) \\
\hline Wild-accession & $9.567^{\mathrm{a}}$ & $4.299^{\mathrm{a}}$ \\
Kirikawadi & $7.058^{\mathrm{c}}$ & $3.909^{\mathrm{b}}$ \\
MU51 & $7.064^{\mathrm{c}}$ & $2.896^{\mathrm{d}}$ \\
CARI555 & $6.914^{\mathrm{c}}$ & $2.883^{\mathrm{d}}$ \\
Shani & $7.347^{\mathrm{c}}$ & $2.424^{\mathrm{e}}$ \\
Suranimala & $6.653^{\mathrm{c}}$ & $2.602^{\mathrm{e}}$ \\
Swarna & $8.967^{\mathrm{b}}$ & $2.608^{\mathrm{e}}$ \\
HordiMU1 & $7.294^{\mathrm{c}}$ & $3.280^{\mathrm{c}}$ \\
Landrace & $7.269^{\mathrm{c}}$ & $2.138^{\mathrm{f}}$ \\
\hline
\end{tabular}

Means denoted by the same letters within the column are not significantly different at $\mathrm{P}<0.05$.

\section{Morphological diversity of tubers}

The highest mean number of tubers was recorded in Suranimala (23.33) which was significantly different from the rest $($ Table $3, \mathrm{P}<0.05)$. The mean weight of tubers was not significantly different among the cultivars $(\mathrm{P}<0.05)$. The highest weight of tubers was observed in the cultivar Suranimala $(\mathrm{P}<0.05)$. None of the parameters; mean minimum length, mean maximum length, mean minimum diameter and mean maximum diameter of tubers were significantly different among cultivars $(\mathrm{P}<0.05)$. Plate 2 displays the morphological variation of tubers and stems of the cultivars. 

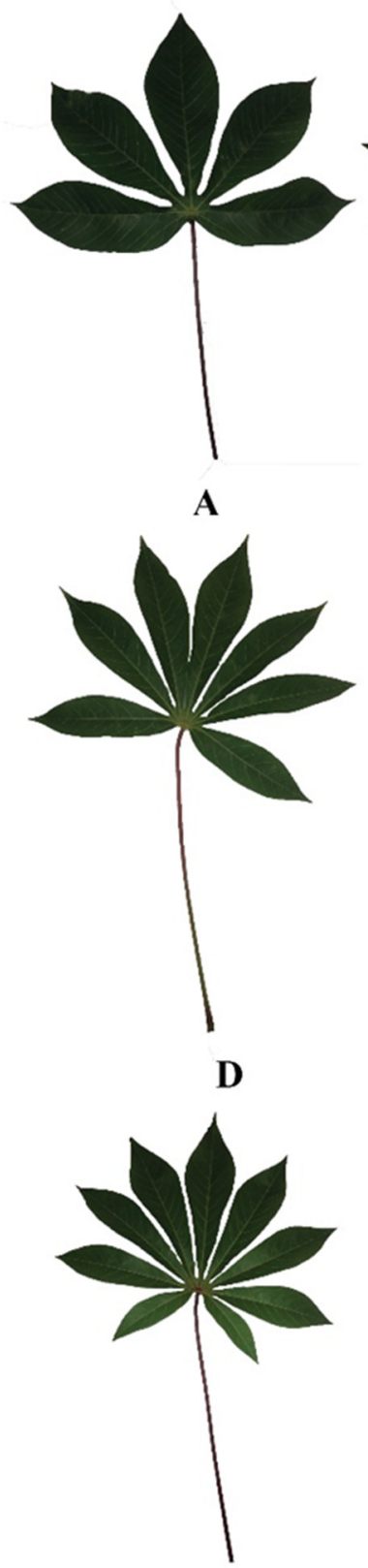

G
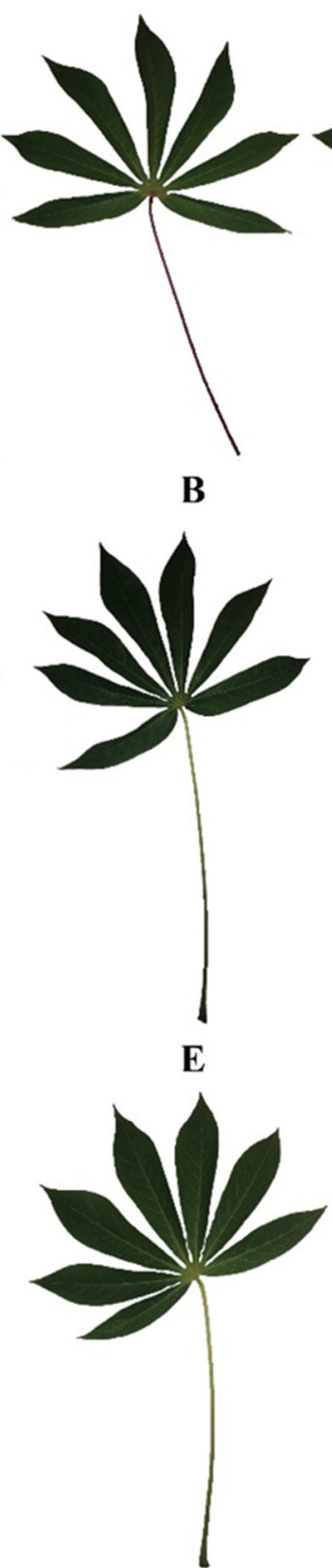

H
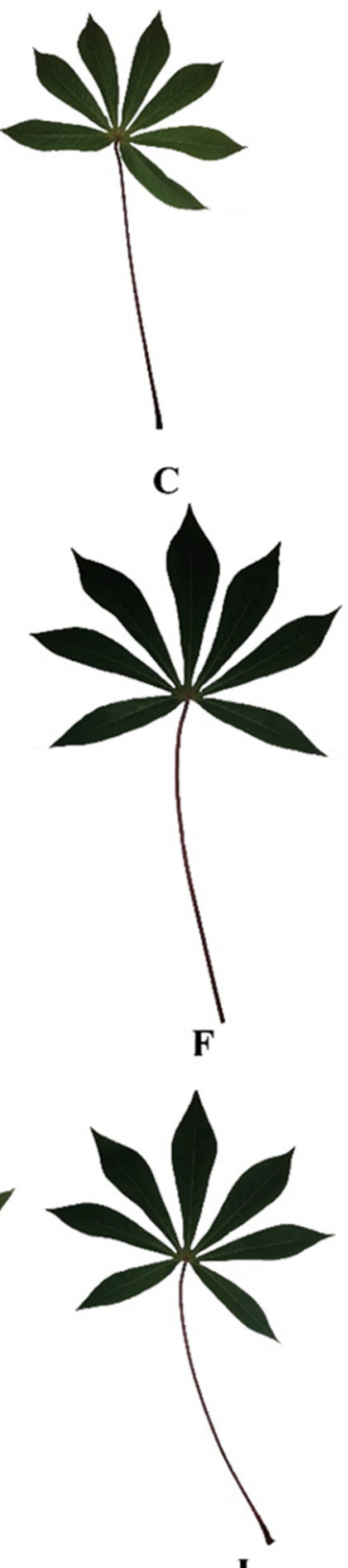

$10 \mathrm{~cm}$

Plate 1. The variation of leaf morphology in cassava leaves. A: Wild-accession, B: Kirikawadi , C: MU51 , D: CARI555, E: Shani , F: Suranimala , G: Swarna , H: HordiMU1, I: Landrace 
Table 3. Variation of tuber morphology

\begin{tabular}{|c|c|c|c|c|c|c|}
\hline Cultivar & $\begin{array}{c}\text { Mean } \\
\text { number } \\
\text { of } \\
\text { tubers }\end{array}$ & $\begin{array}{c}\text { Mean } \\
\text { tuber } \\
\text { weight } \\
(\mathbf{k g})\end{array}$ & $\begin{array}{c}\text { Mean } \\
\text { minimum } \\
\text { length } \\
(\mathrm{cm})\end{array}$ & $\begin{array}{c}\text { Mean } \\
\text { maximum } \\
\text { length } \\
(\mathrm{cm})\end{array}$ & $\begin{array}{c}\text { Mean } \\
\text { minimum } \\
\text { diameter } \\
(\mathrm{cm})\end{array}$ & $\begin{array}{c}\text { Mean } \\
\text { maximum } \\
\text { diameter } \\
(\mathrm{cm})\end{array}$ \\
\hline $\begin{array}{l}\text { Wild- } \\
\text { accession }\end{array}$ & $6.00^{\mathrm{b}}$ & $2.26^{\mathrm{a}}$ & $17.80^{\mathrm{a}}$ & $45.80^{\mathrm{a}}$ & $8.45^{\mathrm{a}}$ & $16.60^{\mathrm{a}}$ \\
\hline Kirikawadi & $12.00^{\mathrm{b}}$ & $7.61^{\mathrm{a}}$ & $12.13^{\mathrm{a}}$ & $49.93^{\mathrm{a}}$ & $8.00^{\mathrm{a}}$ & $23.73^{\mathrm{a}}$ \\
\hline MU51 & $13.00^{\mathrm{b}}$ & $5.80^{\mathrm{a}}$ & $14.97^{\mathrm{a}}$ & $45.00^{\mathrm{a}}$ & $7.07^{\mathrm{a}}$ & $20.50^{\mathrm{a}}$ \\
\hline CARI555 & $8.33^{\mathrm{b}}$ & $2.90^{\mathrm{a}}$ & $13.27^{\mathrm{a}}$ & $36.83^{a}$ & $5.33^{\mathrm{a}}$ & $19.03^{\mathrm{a}}$ \\
\hline Shani & $9.67^{\mathrm{b}}$ & $4.15^{\mathrm{a}}$ & $10.77^{\mathrm{a}}$ & $47.67^{\mathrm{a}}$ & $5.73^{\mathrm{a}}$ & $20.30^{\mathrm{a}}$ \\
\hline Suranimala & $23.33^{\mathrm{a}}$ & $7.81^{\mathrm{a}}$ & $11.93^{\mathrm{a}}$ & $42.23^{\mathrm{a}}$ & $5.20^{\mathrm{a}}$ & $21.43^{\mathrm{a}}$ \\
\hline Swarna & $14.67^{\mathrm{b}}$ & $4.59^{\mathrm{a}}$ & $10.57^{\mathrm{a}}$ & $37.60^{\mathrm{a}}$ & $4.37^{\mathrm{a}}$ & $20.80^{\mathrm{a}}$ \\
\hline HordiMU1 & $13.33^{\mathrm{b}}$ & $4.64^{\mathrm{a}}$ & $11.67^{\mathrm{a}}$ & $43.60^{\mathrm{a}}$ & $4.87^{\mathrm{a}}$ & $21.87^{\mathrm{a}}$ \\
\hline Landrace & $6.67^{b}$ & $2.38^{\mathrm{a}}$ & $9.80^{\mathrm{a}}$ & $32.20^{\mathrm{a}}$ & $5.17^{\mathrm{a}}$ & $19.37^{\mathrm{a}}$ \\
\hline
\end{tabular}

Means denoted by the same letters within the column are not significantly different at $\mathrm{P}<0.05$.

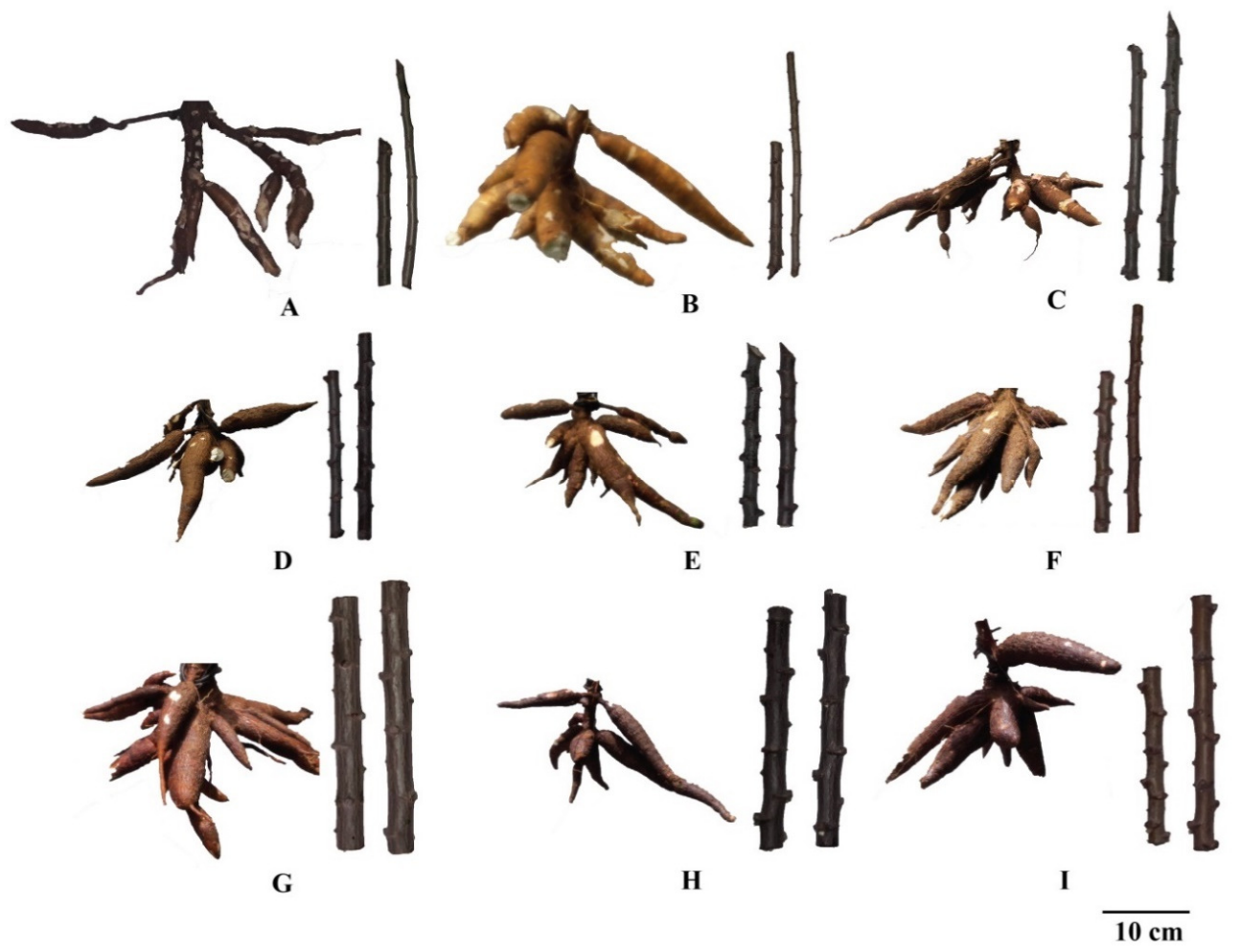

Plate 2. The representative views of cassava tubers and stems. A: Wild-accession, B: Kirikawadi, C: MU51, D: CARI555, E: Shani, F: Suranimala, G: Swarna, H: HordiMU1, I: Landrace . 


\section{Cluster analysis}

When considering the vegetative parameters (Figure 1), Landrace and Wild-accession cultivars were clustered separately from the others. However, when comparing tuber parameters, the Wild-accession grouped with the rest of the cultivars (Figure 2). According to the scatter plot (Figure 2), Wild-accession and Shani clustered together whereas HordiMU1 and Suranimala positioned oppositely. Moreover, Kirikawadi and MU51 placed oppositely to the CARI555, Landrace and Suranimala cultivars. Moreover, Kirikawadi and Suranimala cultivars were different from the rest and the highest yield was observed in Suranimala.

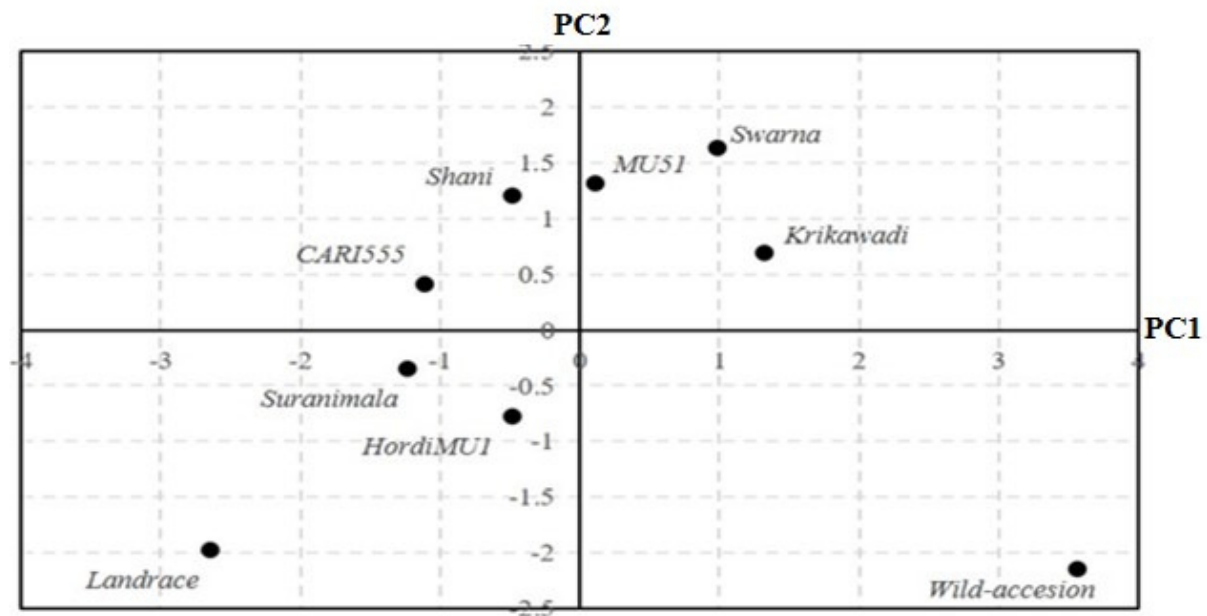

Figure 1. Scatter plot of the PCA conducted for cassava cultivars based on vegetative parameters of leaves and stems using Minitab17. Wild-accession and Landrace cultivars can be discriminated from the rest using vegetative parameters.

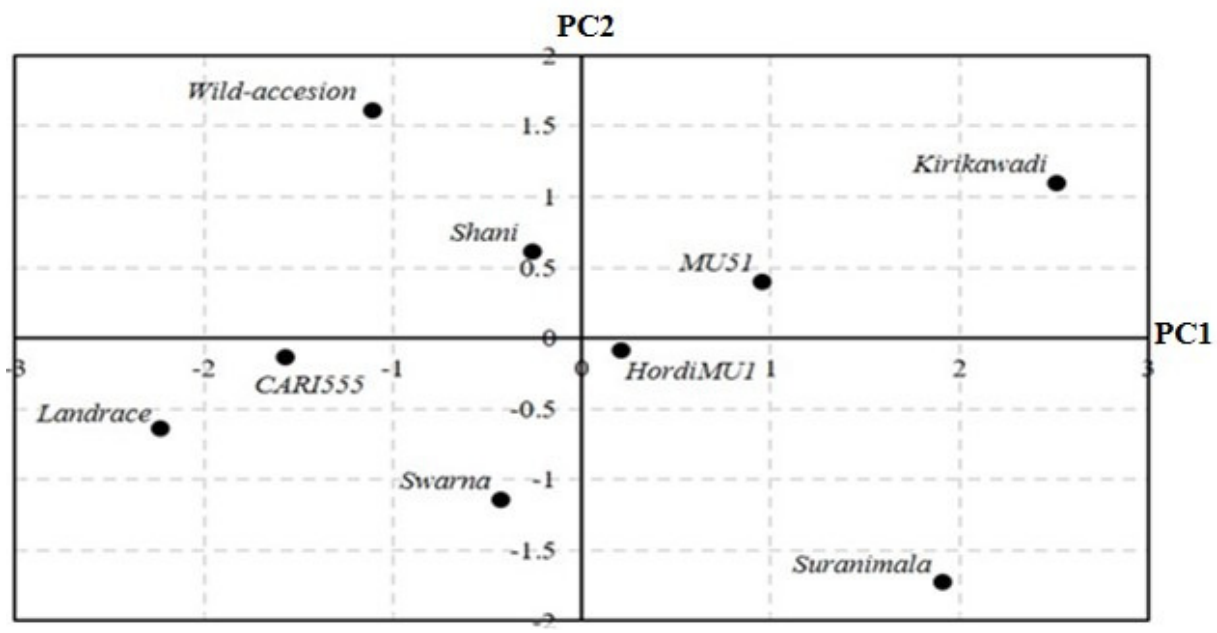

Figure 2. Scatter plot of the PCA conducted for cassava cultivars based on tuber parameters using Minitab17. Kirikawadi and Suranimala cultivars could be discriminated from the rest of the cultivars using tuber parameters. 


\section{Chlorophyll and ascorbic acid contents of leaves}

The mean chlorophyll content of leaves $(232.873 \mathrm{mg} / \mathrm{g})$ and the mean ascorbic acid content of leaves of nine cultivars were not significantly different $(0.0035 \mathrm{~mol} / \mathrm{l})(\mathrm{P}>0.05)$ (Table 4$)$.

\section{Dry matter content}

The mean dry matter content of leaves $(289.290 \mathrm{mg} / \mathrm{g})$ and tubers $(37.583 \mathrm{mg} / \mathrm{g})$ were not significantly different among the cultivars $(\mathrm{P}>0.05)$ (Table 4$)$.

Table 4. Variation of mean chlorophyll, ascorbic acid and dry matter content of leaves

\begin{tabular}{lcccc}
\hline Variety & $\begin{array}{c}\text { Mean Chlorophyll } \\
\text { Content }(\mathbf{m g} / \mathbf{g})\end{array}$ & $\begin{array}{c}\text { Mean Ascorbic } \\
\text { acid content } \\
(\mathbf{m o l} / \mathbf{l})\end{array}$ & $\begin{array}{c}\text { Mean Dry } \\
\text { Matter } \\
\text { Content of } \\
\text { leaves } \\
(\mathbf{m g} / \mathbf{g})\end{array}$ & $\begin{array}{c}\text { Mean Dry } \\
\text { Matter Content } \\
\text { of tubers(\%) }\end{array}$ \\
\hline Wild- & $134.704^{\mathrm{a}}$ & $0.0033^{\mathrm{a}}$ & $316.128^{\mathrm{a}}$ & $46.605^{\mathrm{a}}$ \\
accession & $171.647^{\mathrm{a}}$ & $0.0034^{\mathrm{a}}$ & $304.470^{\mathrm{a}}$ & $40.312^{\mathrm{a}}$ \\
Kirikawadi & $260.647^{\mathrm{a}}$ & $0.0045^{\mathrm{a}}$ & $307.601^{\mathrm{a}}$ & $38.030^{\mathrm{a}}$ \\
MU51 & $217.227^{\mathrm{a}}$ & $0.0030^{\mathrm{a}}$ & $274.998^{\mathrm{a}}$ & $36.779^{\mathrm{a}}$ \\
CARI555 & $279.484^{\mathrm{a}}$ & $0.0038^{\mathrm{a}}$ & $271.973^{\mathrm{a}}$ & $34.689^{\mathrm{a}}$ \\
Shani & $344.092^{\mathrm{a}}$ & $0.0036^{\mathrm{a}}$ & $280.456^{\mathrm{a}}$ & $34.467^{\mathrm{a}}$ \\
Suranimala & $155.993^{\mathrm{a}}$ & $0.0042^{\mathrm{a}}$ & $264.563^{\mathrm{a}}$ & $37.171^{\mathrm{a}}$ \\
Swarna & $245.744^{\mathrm{a}}$ & $0.0026^{\mathrm{a}}$ & $338.739^{\mathrm{a}}$ & $36.625^{\mathrm{a}}$ \\
HordiMU1 & $286.309^{\mathrm{a}}$ & $0.0036^{\mathrm{a}}$ & $244.684^{\mathrm{a}}$ & $33.570^{\mathrm{a}}$ \\
Landrace & & & & \\
\hline
\end{tabular}

Means denoted by the same letters within the column are not significantly different at $\mathrm{P}<0.05$

\section{Relationship between chlorophyll content and the mean dry matter content of leaves}

According to the regression relationship between the chlorophyll content and leaf dry matter content (Figure 3), $\mathrm{R}^{2}$ value was recorded as 0.078 . The highest leaf dry matter obtained for HordiMU1. Although it had the highest leaf dry mater content MU51, Shani, Landrace and Suranimala had the highest chlorophyll content. Similarly, even though Suranimala got the highest chlorophyll content, Shani, HordiMU1, Kirikawadi and Wild-accessions reported higher amount of leaf dry matter content than Suranimala. 


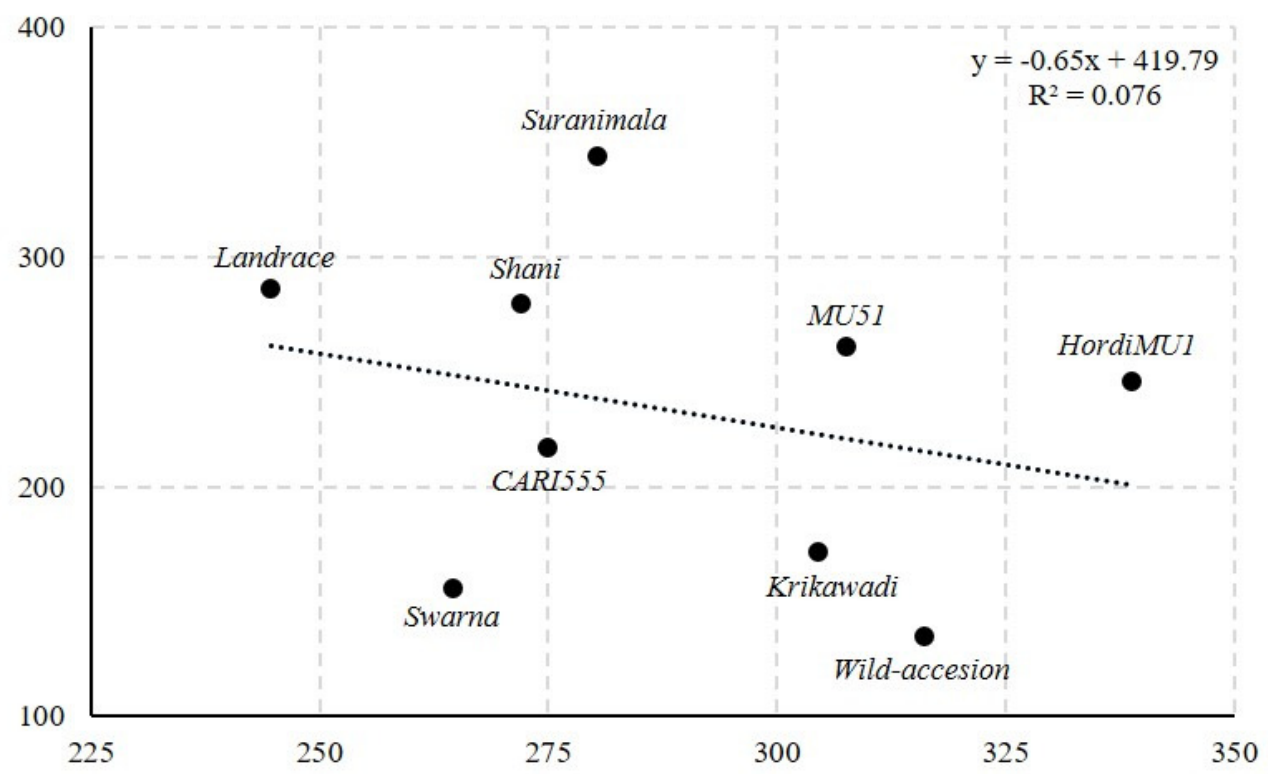

Figure 3. Regression relationship between chlorophyll content $(X)$ and leaf dry matter content (Y).

The boiled tuber samples used for the taste panel analysis are given in Plate 3. Boiled tuber pieces of Wild-accession and MU51 were observed with intense yellow color whereas the cultivars Kirikawadi and Swarna showed less intense yellow color. Tuber pieces of CARI555, Shani, Suranimala and HordiMU1 appeared similar showing whitish yellow color and Landrace cultivar looked light yellow in color (Plate 3). Association analysis of cassava cultivars with all the tested parameters (desired color, the preferred levels of aroma, the texture, bitterness, hardness and overall taste) showed significant association at $\mathrm{P}<0.05$ (Table 5). The highest association was observed between the cassava cultivar and the overall taste $\left(\chi^{2}=\right.$ 107.70) followed by the association between cassava cultivar and the hardness $\left(\chi^{2}=88.74\right)$, texture $\left(\chi^{2}=80.35\right)$, color $\left(\chi^{2}=47.19\right)$ and aroma $\left(\chi^{2}=30.88\right)$. However, the strength of the association was weak as indicated by Cramer's V-square (Table 5). Association between the color and the other parameters were also significant whereas color and the overall taste showed the highest association $\left(\chi^{2}=80.69\right)$. Texture, bitterness, hardness and overall taste were significantly associated with aroma. Similarly, overall taste showed the highest association with the aroma $\left(\chi^{2}=92.34\right)$. The texture was significantly associated with the bitterness, hardness and overall taste. As observed previously, the highest association was observed between texture and the overall taste $\left(\chi^{2}=216.42\right)$. Association between the bitterness was significant with hardness $\left(\chi^{2}=70.52\right)$ and overall taste $\left(\chi^{2}=95.00\right)$ but the hardness was only significantly associated with the overall taste $\left(\chi^{2}=197.18\right)$.

The row percentages given in Table 5 of the significant associations revealed that the desired level of color was highest for MU51, medium for HordiMU1 and least for Suranimala. The highest preference level of aroma was observed in Kirikawadi (38\%) whereas HordiMU1 received the least preferred level of aroma (28\%). The highest preference level of texture was observed in MU51 whereas Wild-accession reported the least preferred level of texture (Table $5, \mathrm{P}<0.05)$. The degree of bitterness was highest for CARI555, medium for Suranimala and least for Kirikawadi. Preference level of hardness was highest for MU51 and least for Wild- 
accession. Kirikawadi reported the highest preferred level of overall taste whereas Shani reported the medium level and the least preferred level of overall taste was observed for Landrace.

Table 5. Association analysis of the taste parameters and the Cassava cultivars.

\begin{tabular}{|c|c|c|c|c|c|c|}
\hline & & & & $\begin{array}{l}\text { Pearson } \\
\chi^{2}\end{array}$ & P-Value & $\begin{array}{l}\text { Cramer's } \\
\text { V-square }\end{array}$ \\
\hline \multicolumn{7}{|c|}{ Cassava cultivar vs. Desired Color } \\
\hline \multirow{2}{*}{$\begin{array}{l}\text { Cassava } \\
\text { Cultivar }\end{array}$} & \multicolumn{3}{|c|}{ Desired Colour } & \multirow{11}{*}{47.19} & \multirow{11}{*}{0.000} & \multirow{11}{*}{0.05} \\
\hline & Low(1) & Medium(2) & $\operatorname{High}(3)$ & & & \\
\hline $\begin{array}{l}\text { Wild- } \\
\text { accession }\end{array}$ & $12 \%$ & $55 \%$ & $33 \%$ & & & \\
\hline Kirikawadi & $12 \%$ & $37 \%$ & $51 \%$ & & & \\
\hline MU51 & $7 \%$ & $41 \%$ & $52 \%$ & & & \\
\hline CARI555 & $27 \%$ & $51 \%$ & $22 \%$ & & & \\
\hline Shani & $18 \%$ & $52 \%$ & $30 \%$ & & & \\
\hline Suranimala & $35 \%$ & $45 \%$ & $20 \%$ & & & \\
\hline Swarna & $13 \%$ & $45 \%$ & $42 \%$ & & & \\
\hline HordiMU1 & $23 \%$ & $58 \%$ & $19 \%$ & & & \\
\hline Landrace & $22 \%$ & $48 \%$ & $30 \%$ & & & \\
\hline \multicolumn{7}{|c|}{ Cassava cultivar vs. Preferred level of Aroma } \\
\hline \multirow{2}{*}{$\begin{array}{l}\text { Cassava } \\
\text { Cultivar }\end{array}$} & \multicolumn{3}{|c|}{ Preferred level of Aroma } & \multirow{11}{*}{30.88} & \multirow{11}{*}{0.006} & \multirow{11}{*}{0.03} \\
\hline & Low(1) & Medium(2) & $\operatorname{High}(3)$ & & & \\
\hline $\begin{array}{l}\text { Wild- } \\
\text { accession }\end{array}$ & $25 \%$ & $65 \%$ & $10 \%$ & & & \\
\hline Kirikawadi & $7 \%$ & $55 \%$ & $38 \%$ & & & \\
\hline MU51 & $8 \%$ & $55 \%$ & $37 \%$ & & & \\
\hline CARI555 & $25 \%$ & $53 \%$ & $22 \%$ & & & \\
\hline Shani & $27 \%$ & $50 \%$ & $23 \%$ & & & \\
\hline Suranimala & $20 \%$ & $50 \%$ & $30 \%$ & & & \\
\hline Swarna & $20 \%$ & $60 \%$ & $20 \%$ & & & \\
\hline HordiMU1 & $28 \%$ & $52 \%$ & $20 \%$ & & & \\
\hline Landrace & $13 \%$ & $55 \%$ & $32 \%$ & & & \\
\hline \multicolumn{7}{|c|}{ Cassava cultivar vs. Preferred level of Texture } \\
\hline \multirow{2}{*}{$\begin{array}{l}\text { Cassava } \\
\text { Cultivar }\end{array}$} & \multicolumn{3}{|c|}{ Preferred level of Texture } & \multirow{11}{*}{80.35} & \multirow{11}{*}{0.000} & \multirow{11}{*}{0.08} \\
\hline & Low(1) & Medium(2) & $\operatorname{High}(3)$ & & & \\
\hline $\begin{array}{l}\text { Wild- } \\
\text { accession }\end{array}$ & $55 \%$ & $38 \%$ & $7 \%$ & & & \\
\hline Kirikawadi & $10 \%$ & $38 \%$ & $52 \%$ & & & \\
\hline MU51 & $7 \%$ & $28 \%$ & $65 \%$ & & & \\
\hline CARI555 & $17 \%$ & $46 \%$ & $37 \%$ & & & \\
\hline Shani & $23 \%$ & $54 \%$ & $23 \%$ & & & \\
\hline Suranimala & $23 \%$ & $54 \%$ & $23 \%$ & & & \\
\hline Swarna & $15 \%$ & $47 \%$ & $38 \%$ & & & \\
\hline HordiMU1 & $27 \%$ & $43 \%$ & $30 \%$ & & & \\
\hline Landrace & $10 \%$ & $47 \%$ & $43 \%$ & & & \\
\hline \multicolumn{7}{|c|}{ Cassava cultivar vs. Degree of Bitterness } \\
\hline \multirow{2}{*}{$\begin{array}{l}\text { Cassava } \\
\text { Cultivar }\end{array}$} & Preferre & el of Texture & & \multirow{4}{*}{26.87} & \multirow{4}{*}{0.015} & \multirow{4}{*}{0.03} \\
\hline & Low(1) & Medium(2) & $\operatorname{High}(3)$ & & & \\
\hline $\begin{array}{l}\text { Wild- } \\
\text { accession }\end{array}$ & $40 \%$ & $40 \%$ & $20 \%$ & & & \\
\hline Kirikawadi & $68 \%$ & $20 \%$ & $12 \%$ & & & \\
\hline
\end{tabular}




\begin{tabular}{|c|c|c|c|c|c|c|}
\hline & & & & $\begin{array}{l}\text { Pearson } \\
\chi 2\end{array}$ & P-Value & $\begin{array}{l}\text { Cramer's } \\
\text { V-square }\end{array}$ \\
\hline MU51 & $60 \%$ & $25 \%$ & $15 \%$ & & & \\
\hline CARI555 & $47 \%$ & $28 \%$ & $25 \%$ & & & \\
\hline Shani & $44 \%$ & $38 \%$ & $18 \%$ & & & \\
\hline Suranimala & $36 \%$ & $42 \%$ & $22 \%$ & & & \\
\hline Swarna & $58 \%$ & $35 \%$ & $7 \%$ & & & \\
\hline HordiMU1 & $56 \%$ & $32 \%$ & $12 \%$ & & & \\
\hline Landrace & $63 \%$ & $27 \%$ & $10 \%$ & & & \\
\hline \multicolumn{7}{|c|}{ Cassava cultivar vs. Preferred level of Hardness } \\
\hline \multirow{2}{*}{$\begin{array}{l}\text { Cassava } \\
\text { Cultivar }\end{array}$} & \multicolumn{3}{|c|}{ Preferred level of Hardness } & \multirow{11}{*}{88.74} & \multirow{11}{*}{0.000} & \multirow{11}{*}{0.09} \\
\hline & Low(1) & Medium(2) & $\operatorname{High}(3)$ & & & \\
\hline $\begin{array}{l}\text { Wild- } \\
\text { accession }\end{array}$ & $48 \%$ & $45 \%$ & $7 \%$ & & & \\
\hline Kirikawadi & $15 \%$ & $25 \%$ & $60 \%$ & & & \\
\hline MU51 & $5 \%$ & $23 \%$ & $72 \%$ & & & \\
\hline CARI555 & $18 \%$ & $33 \%$ & $49 \%$ & & & \\
\hline Shani & $30 \%$ & $50 \%$ & $20 \%$ & & & \\
\hline Suranimala & $23 \%$ & $47 \%$ & $30 \%$ & & & \\
\hline Swarna & $18 \%$ & $43 \%$ & $39 \%$ & & & \\
\hline HordiMU1 & $32 \%$ & $43 \%$ & $25 \%$ & & & \\
\hline Landrace & $8 \%$ & $40 \%$ & $52 \%$ & & & \\
\hline \multicolumn{7}{|c|}{ Cassava cultivar vs. Preferred level of Overall Taste } \\
\hline \multirow{2}{*}{$\begin{array}{l}\text { Cassava } \\
\text { Cultivar }\end{array}$} & \multicolumn{3}{|c|}{ Preferred level of Overall Taste } & \multirow{11}{*}{107.70} & \multirow{11}{*}{0.000} & \multirow{11}{*}{0.10} \\
\hline & Low(1) & Medium(2) & High(3) & & & \\
\hline $\begin{array}{l}\text { Wild- } \\
\text { accession }\end{array}$ & $35 \%$ & $62 \%$ & $3 \%$ & & & \\
\hline Kirikawadi & $8 \%$ & $25 \%$ & $67 \%$ & & & \\
\hline MU51 & $7 \%$ & $33 \%$ & $60 \%$ & & & \\
\hline CARI555 & $12 \%$ & $60 \%$ & $28 \%$ & & & \\
\hline Shani & $18 \%$ & $68 \%$ & $19 \%$ & & & \\
\hline Suranimala & $27 \%$ & $50 \%$ & $23 \%$ & & & \\
\hline Swarna & $18 \%$ & $45 \%$ & $37 \%$ & & & \\
\hline HordiMU1 & $37 \%$ & $35 \%$ & $28 \%$ & & & \\
\hline Landrace & $7 \%$ & $48 \%$ & $45 \%$ & & & \\
\hline
\end{tabular}




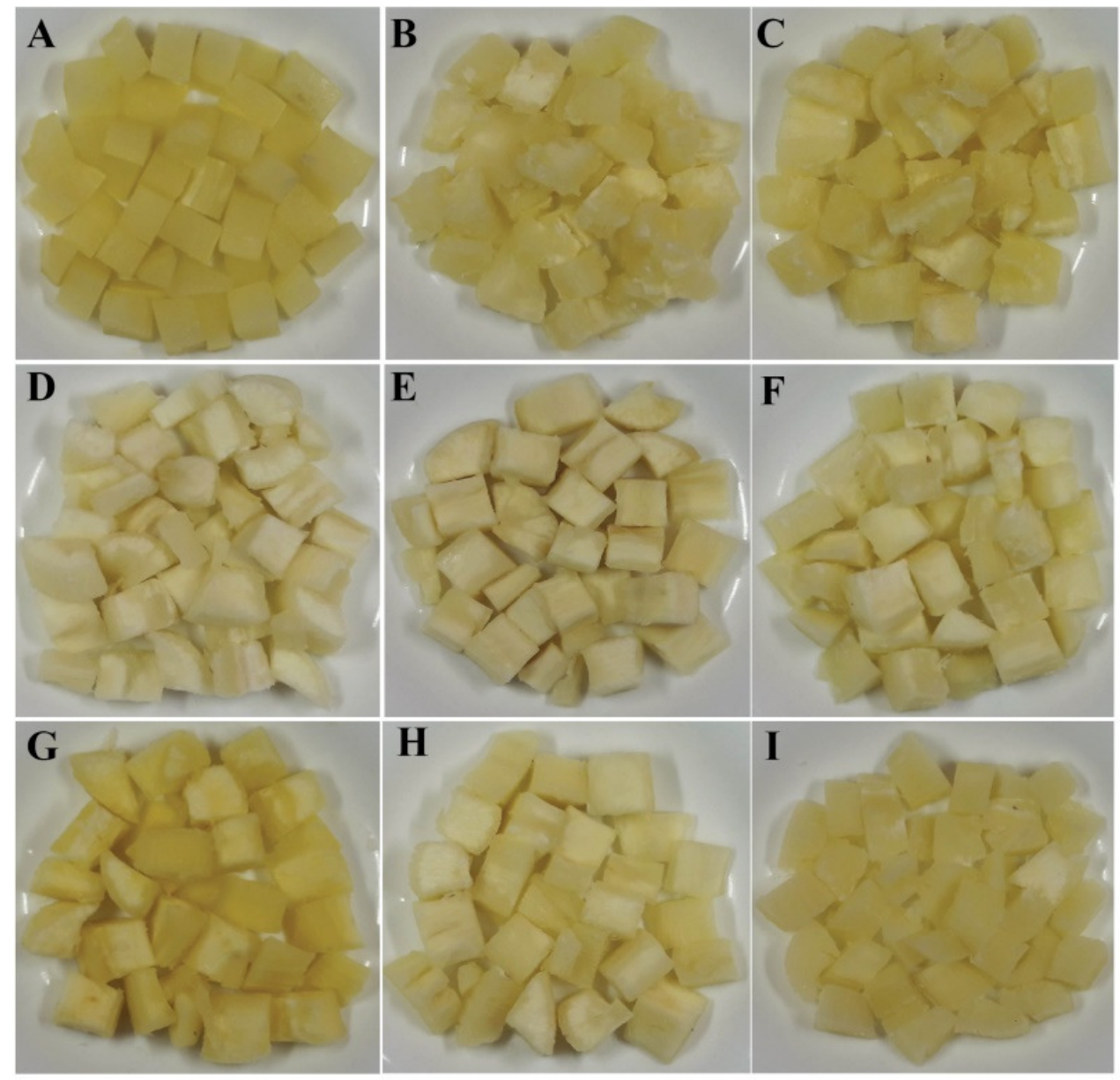

$\overline{10 \mathrm{~cm}}$

Plate 3. The images of boiled cassava tubers. A: Wild-accession, B: Kirikawadi, C: MU51, D: CARI555, E: Shani, F: Suranimala, G: Swarna, H: HordiMU1, I: Landrace.

\section{Cluster analysis of organoleptic assessment}

According to the dendrogram constructed with consumer preference data, three clusters were observed around $60 \%$ similarity level in which the Wild-accession was clustered separately from the rest of the cultivars (Figure 4). However, around $90 \%$ similarity level, all the cultivars are grouped into individual clusters (Figure 4). 


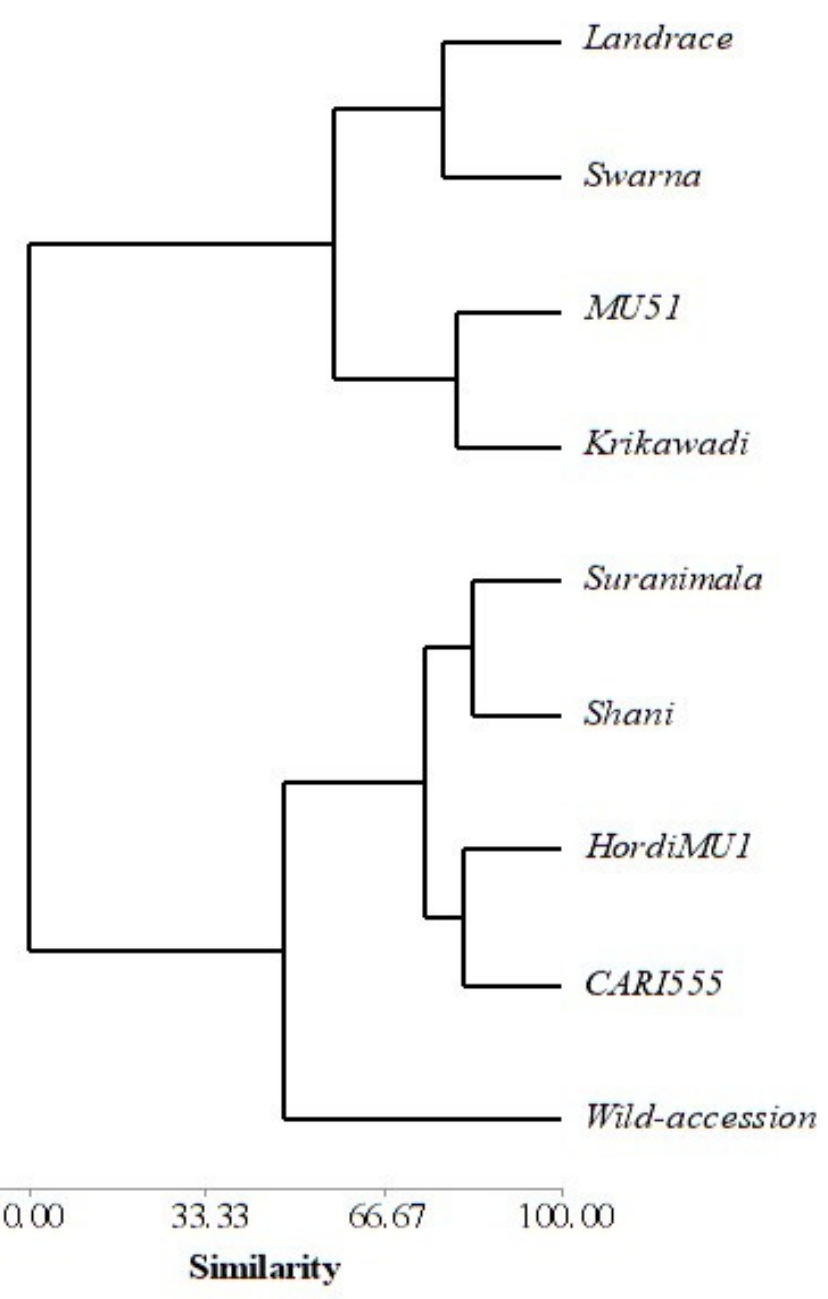

Figure 4. Dendrogram of consumer preferences analysis constructed using Mintab17. Wild-accession has a different consumer preference levels than the other cultivars.

\section{ITS based DNA barcoding}

According to the dendrogram obtained, SNPs and INDELS of ITS genomic region were able to distinguish nine cassava cultivars into eight individual groups at a genetic divergence level of 0.0025 . Among nine cassava cultivars, the Wild-accession was the most distinctly resolving subject from the rest of the cultivars holding unique mutations (Figure 5). Nucleotide substitutions of $\mathrm{C}$ to $\mathrm{T}$ at four positions $(23,73,322$ and 380) and $\mathrm{T}$ to $\mathrm{C}$ substitution at two positions (42 and 53) observed in Wild-accession was unique and the INDEL found at the $384^{\text {th }}$ position of the nucleotide sequence is also unique for the Wild-accession. Other than that, there were nucleotide substitutions found only in Wild-accession at the positions of 89, 146, 368 and 515 (G89A, A146G, A368T, and A515G) further increasing the discrimination power. Rest of the eight cultivars was clustered mainly into two groups at a genetic divergence of 0.0037 . Among the eight cultivars, Shani, Suranimala, Landrace, Kirikawadi, and CARI555 were 
clustered into one clade sharing two unique SNPs of G at $11^{\text {th }}$ and $14^{\text {th }}$ positions whereas MU51, HordiMU1 and Swarna were clustered into the other clade sharing the unique SNPs of $\mathrm{A}$ at the same two positions. The generated sequences in the present study were submitted to GenBank under the accession numbers MK114626-MK114634 (www.ncbi.nlm.nih.gov).

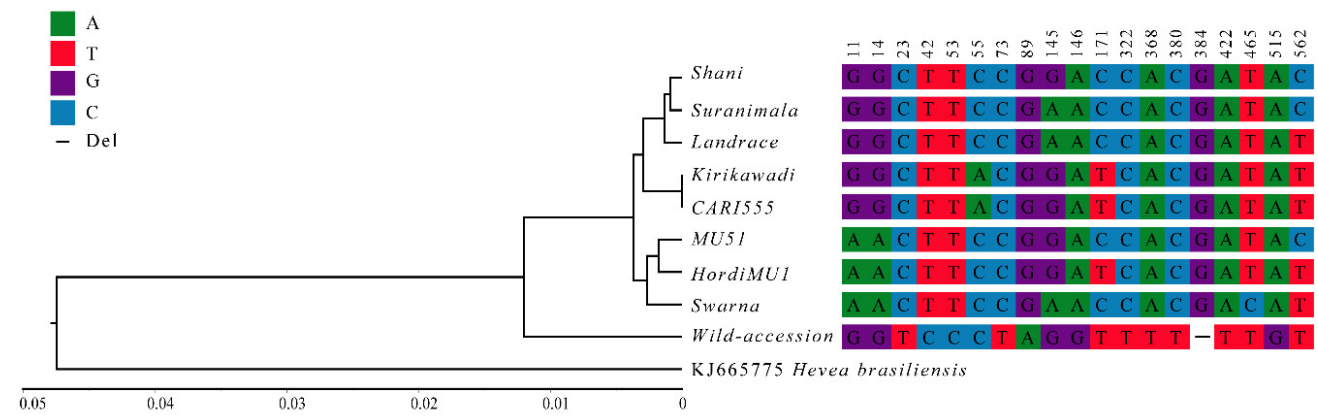

\section{Figure 5. Cultivar discrimination based on UPGMA tree construction and SNP profiling of the ITS region. The $\mathrm{X}$-axis represents the uncorrected pairwise distance. SNP profile is shown next to the tree.}

A cultivar description based on precise molecular, morphological and organoleptic parameters, chlorophyll and ascorbic acid contents of leaves, and dry matter content was done in the present study. Only some of the morphological parameters (mean number of leaflets, mean diameter and mean internodal length of stems) could be used to discriminate among cultivars, however, they were not helpful in discriminating the cultivars at initial stages of plant growth. However, none of the parameters including mean chlorophyll content and mean ascorbic acid content could not be used to differentiate the cultivars (Table 4). The application of DNA based identification methods can be used for the precise molecular identification of cassava cultivars in Sri Lanka. In addition, the detected ITS sequences for each cultivar could be used as DNA barcodes to authenticate cassava cultivars in the export market. However, another barcode must be sorted to discriminate the Kirikawadi and CARI555.

The results revealed that the Landrace cultivar was significantly different from the other cultivars by mean leaf length, mean leaf width and mean leaf area. The mean number of leaflets of the Landrace cultivar was not significantly different from that of Kirikawadi, Suranimala, and HordiMU1. Wild-accession was significantly different from other cultivars by mean leaf width and mean number of leaflets and it showed the highest mean leaf width compared to the others. The lowest leaf length, leaf width and leaf area were observed in the Landrace cultivar whereas the lowest number of leaflets was observed in the Wild-accession. Except for Landrace, the mean length of leaves and mean leaf area of other cultivars were not significantly different from each other. Weak relationships were observed between mean length of leaves and cultivar; mean width of leaves and cultivar; and mean leaf area and cultivar whereas a strong relationship was observed between the mean number of leaflets and cultivar (Plate 1). When stem morphology was considered, Wild-accession showed significantly highest mean diameter of stems followed by Swarna whereas the other cultivars were not significantly different from each other by the mean diameter of stems (Plate 2). The mean internodal length of stems of nine cultivars was significantly different $(\mathrm{P}<0.05)$. 
Suranimala cultivar had the significantly highest mean number of tubers $(\mathrm{P}<0.05)$. All the other morphological characters of tubers including the mean weight of tubers, mean maximum and minimum lengths of tubers and mean maximum and minimum diameter of tubers were not significantly different among the nine cultivars. Strong relationships were observed among all the tubers mentioned above characters (including the number of tubers) and cultivars. Thus, this could be used to discriminate the cultivars employed in this study.

Taste panel data revealed that MU51 has the highest desired level of color whereas the Suranimala cultivar has the least and HordiMU1 has the medium. The association between cassava cultivar and preference level of aroma indicated that HordiMU1 has the least preference over the rest of the cultivars whereas the highest preference was observed in Kirikawadi (Figure 1). Similarly, in terms of desired level of texture and hardness, MU51 has the highest preference and the Wild-accession has the least preference. Kirikawadi cultivar shows the least degree of bitterness and the highest preference level of overall taste (Figure 1). Considering the association between cassava cultivar and the preference level of the overall taste, Landrace has the least preference over the rest of the cultivars. All the possible combinations of the parameters mentioned above, such as color and aroma, overall taste and hardness, texture and bitterness are significantly associated. The bitterness of cassava was found to be related to the content of cyanoglucoside in sensory evaluation of 38 cassava strains (Sundaresan et al., 1987). There were no significant differences among the nine cultivars with regard to other parameters including chlorophyll content of leaves, the ascorbic acid content of leaves and dry matter content of leaves and tubers. Using vegetative parameters Wildaccession can be clearly discriminated from rest of the cultivars (Figure 1). Whereas other cultivars cannot be categorized using vegetative parameters. According to the scattered plot obtained for the tuber parameters (Figure 2) Kirikawadi and Suranimala can be differentiated from rest of the cultivars. However, rest of the cultivars could not be distinguished using tuber parameters. The regression model accounts for $7.62 \%$ of the variation (Figure 3 ). There is no any significant relationship among chlorophyll and the leaf dry matter contents. According to the organoleptic parameters, Wild-accession has a much varied preference level than the other cultivars (Figure 4). It can be inferred that Wild-accession is not preferred by the people compared to the other cultivars. A clear cultivar separation was obtained from the distance tree construction for ITS genomic region. Total of 18 SNPs and one INDEL was observed in ITS region for the nine cultivars (Figure 3). The Wild-accession was traced (0.0075) from the rest of the group sharing unique SNP position concerning other groups. This is the first study to report the divergence between commercial cassava cultivars and wild cassava accession found in Sri Lankan habitats. It is important to infer the molecular phylogeny of wild cassava accession compared to other cultivars which implied from the ITS haplotype. It is essential to carry out a complete, molecular systematic study of wild cassava accession as it could be a new species.

\section{CONCLUSIONS}

Morphological assessment of the nine cassava cultivars indicated that the leaf morphology of Wild-accession and Landrace cultivars is significantly different from the rest of the cultivars. Stem morphology among the nine cultivars is significantly different mainly by the mean internodal length of the stems whereas Wild-accession and Swarna cultivars are significantly different from the rest by the diameter of the stems. With regard to tuber morphology, Suranimala cultivar is significantly different in comparison to other cultivars in tuber morphology. The taste panel revealed that the cassava cultivars Wild-accession, Kirikawadi, MU51, CARI555, Shani, Suranimala, Swarna, HordiMU1 and Landrace have significantly 
different levels of preferred color, texture, aroma, hardness, overall taste and degree of bitterness. The MU51 has the highest preferred color, texture, and hardness, while Kirikawadi shows the highest preference levels of aroma and overall taste. CARI555 has the highest degree of bitterness. When the other parameters of leaves and tubers of cassava cultivars including chlorophyll content of leaves, the ascorbic content of leaves and dry matter content of leaves and tubers are considered, no significant differences were observed among the cassava cultivars $(232.873 \mathrm{mg} / \mathrm{g}, 0.0035 \mathrm{~mol} / \mathrm{l}, 289.290 \mathrm{mg} / \mathrm{g}, 37.583 \%$ respectively). The ITS DNA barcoding marker ably separated the cultivars. Altogether, 18 SNPs were identified, nine of them were unique to Wild-accession. It has diverged from the rest of the cultivars elevating the importance of doing further taxonomic studies.

\section{ACKNOLEDGEMENT}

Authors wish to acknowledge Mr. U. Seneviratne, Assistant Director of Department of Agriculture, Peradeniya.

\section{REFERENCES}

Adelekan, B.A. (2010). Investigation of ethanol productivity of cassava crop as a sustainable source of biofuel in tropical countries. Afr. J. Biotechnol. 9 (35), 5643-5650.

Beeching, J.R., Marmey, P., Gavalda, M.C., Noirot, M., Haysom, H.R., Hughes, M.A. and Charrier, A. (1993). An assessment of genetic diversity within a collection of cassava (Manihot esculenta Crantz) germplasm using molecular markers. Ann. Bot. 72 (6), 515-520.

Carvalho. L.J. and Schaal, B.A. (2001). Assessing genetic diversity in the cassava (Manihot esculenta Crantz) germplasm collection in Brazil using PCR-based markers. Euphytica. 120 (1), 133-142.

Chavarriaga-Aguirre, P., Maya, M.M., Tohme, J., Duque, M.C., Iglesias, C., Bonierbale, M.W., Kresovich, S. and Kochert, G. (1999). Using microsatellites, isozymes and AFLPs to evaluate genetic diversity and redundancy in the cassava core collection and to assess the usefulness of DNA-based markers to maintain germplasm collections. Mol. Breed. 5 (3), 263 273.

Cock, J.H. (1982). Cassava: a basic energy source in the tropics. Science. 218 (4574), 755762.

Conopsea, G. and Bifolia, P. (2017). The ability of spontaneous autogamy in four orchid species: Cephalanthera rubra, neottia ovata. ACTA BIOL CRACOV BOT, 59 (2), 51-61.

Da Silva, R.M., Bandel, G. and Martins, P.S. (2003). Mating system in an experimental garden composed of cassava (Manihot esculenta Crantz) ethnovarieties. Euphytica. 134 (2), 127-135.

Doyle, J. (1991). DNA protocols for plants. In Molecular techniques in taxonomy Springer, Berlin, Heidelberg, pp. 283-293.

Elias, M., Penet, L., Vindry, P., McKey, D., Panaud, O. and Robert, T. (2001). Unmanaged sexual reproduction and the dynamics of genetic diversity of a vegetatively propagated crop 
plant, cassava (Manihot esculenta Crantz), in a traditional farming system. Mol Ecol. 10 (8), 1895-907.

El-Sharkawy, M.A. (2003). Cassava biology and physiology. Plant Mol. Biol. 53 (5), 621-641.

Fregene, M.A., Suarez, M., Mkumbira, J., Kulembeka, H., Ndedya, E., Kulaya, A., Mitchel, S., Gullberg, U., Rosling, H., Dixon, A.G. and Dean, R. (2003). Simple sequence repeat marker diversity in cassava landraces: genetic diversity and differentiation in an asexually propagated crop. Theor Appl Genet. 107 (6), 1083-1093.

Glass, N.L. and Donaldson, G.C. (1995). Development of primer sets designed for use with the PCR to amplify conserved genes from filamentous ascomycetes. Appl. Environ. Microbiol. 61(4), 1323-1330.

Hershey, C.H., (2017). Breeding, delivery, use and benefits of bio-fortified cassava Elizabeth Parkes and Olufemi Aina, International Institute of Tropical Agriculture (IITA), Nigeria. In Achieving sustainable cultivation of cassava (Volume 2). Burleigh Dodds Science Publishing, pp. 191-203.

Jansson, C., Westerbergh, A., Zhang, J., Hu, X. and Sun, C. (2009). Cassava, a potential biofuel crop in (the) People's Republic of China. Appl Energy. 86, 95-99.

Jimenez-Nieto, A. (1994). Identificación de duplicados del banco de germoplasma de yuca (Manihot esculenta Crantz) del CIAT, B.S. thesis. Universidad Nacional de Colombia, Palmira, Colombia

Jose, A., Makeshkumar, T. and Edison, S. (2008). Host range of Sri Lankan cassava mosaic virus. J Root Crops. 34, 21-25.

Kawuki, R.S., Ferguson, M., Labuschagne, M., Herselman, L. and Kim, D.J. (2009). Identification, characterisation and application of single nucleotide polymorphisms for diversity assessment in cassava (Manihot esculenta Crantz). Mol. Breed. 23 (4), 669-684.

Kruglyak, L. (1997). The use of a genetic map of biallelic markers in linkage studies. Nat. Genet. 17 (1), 21.

Kumar, S., Stecher, G. and Tamura, K. (2016). MEGA7: Molecular Evolutionary Genetics Analysis version 7.0 for bigger datasets. Mol Biol Evol. 33 (7), 1870-1874.

Kumarasinghe, N., Salim, N. and Wijayarathne, W. (2009). Identification and biology of two whitefly species on cassava in Sri Lanka. Journal of plant protection research. 49 (4), 373-377.

Lefevre, F. (1989). Ressources Génétiques et amelioration du Manihoc, Manihot esculenta Crantz, en Afrique. Institut National Agronomique Paris-Grignon, Paris, France, pp.176.

Lopez, C., Piegu, B., Cooke, R., Delseny, M., Tohme, J. and Verdier, V. (2005). Using cDNA and genomic sequences as tools to develop SNP strategies in cassava (Manihot esculenta Crantz). Theor. Appl. Genet. 110 (3), 425-431. 
Maclachlan, S. and Zalik, S. (1963). Plastid structure, chlorophyll concentration, and free amino acid composition of a chlorophyll mutant of barley. Can J Bot. 41(7), 1053-1062.

Marmey, P., Beeching, J.R., Hamon, S. and Charrier, A. (1993). Evaluation of cassava (Manihot esculenta Crantz) germplasm collections using RAPD markers. Euphytica. 74 (3), 203-209.

Meghji, M.R., Dudley, J.W., Lambert, R.J. and Sprague, G.F. (1984). Inbreeding Depression, Inbred and Hybrid Grain Yields, and Other Traits of Maize Genotypes Representing Three Eras 1. Crop Sci. 24 (3), 545-549.

Moyib, O.K., Odunola, O.A. and Dixon, A.G.O. (2007). SSR markers reveal genetic variation between improved cassava cultivars and landraces within a collection of Nigerian cassava germplasm. Afr. J. Biotechnol. 6 (23), 2666-2674.

Ocampo, C., Hershey, C.H., Iglesias, F. and Iwanaga, M. (1993). Esterase isozyme fingerprinting of the cassava germplasm collection held at nCIAT. In: Roca W, Thro AM (eds) Proc 1st Int Sci Meet Cassava Biotechnol Network. CIAT, Cali, Colombia, pp 81-89.

Rambaut, A. (2014) FigTree, a graphical viewer of aphylogenetic trees [online]. Available on: http://tree. bio. ed.ac. uk/software/figtree. (Date of access: 20.08.2017).

Reynolds, S.M., (2017). SNP-based genetic linkage mapping and whole-genome diversity assessment in cassava (Manihot esculenta Crantz) accessions from Africa and Latin America (Doctoral dissertation, University of Pretoria).

Rodriguez, A. and Sanders, I.R. (2015). The role of community and population ecology in applying mycorrhizal fungi for improved food security. ISME J.9 (5),1053.

Rojas, M.C., Pérez, J.C., Ceballos, H., Baena, D., Morante, N. and Calle, F. (2009). Analysis of inbreeding depression in eight $S 1$ cassava families. Crop Sci. 49 (2), 543-548.

Sundaresan, S., Nambisan, B. and Amma, C.S.E. (1987). Bitterness in cassava in relation to cyanoglucoside content'. Indian J Agr Sci., 57(1), 37-40.

Swofford, D.L. (2001). Paup*: Phylogenetic analysis using parsimony (and other methods) 4.0. B5.

White, T.J., Bruns, T., Lee, S. and Taylor, J. (1990). In: Innis, A., Gelfand, D.H., Sninsky, J. J. (Eds.), PCR Protocols, Academic Press, San Diego, USA, pp.315-322.

Ziska, L.H., Runion, G.B., Tomecek, M., Prior, S.A., Torbet, H.A. and Sicher, R. (2009). An evaluation of cassava, sweet potato and field corn as potential carbohydrate sources for bioethanol production in Alabama and Maryland. Biomass Bioenergy. 33 (11), 1503-1508. 